\section{Petroleum congress}

\section{London gathering optimistic}

THE Eleventh World Petroleum Congress, marked the fiftieth anniversary of the first such meeting, also in London. This round date inevitably gave a certain historical perspective to an otherwise routine forum for the exchange of technical expertise. The mood, however, was forward rather than backward looking, although the Polish delegation took the opportunity to host a slightly belated commemoration of the centenary, last year, of the death of Ignacy Lukasiewicz, whose invention in 1853 of the kerosene lamp effectively launched the modern petrochemical industry. Where more modern history impinged on the congress, the results were less happy - the Argentinian delegation arrived without its technical handouts, which had apparently been impounded by the British customs authorities.

The general theme of the congress, petroleum in the twenty-first century, both refelected the "historic" aspect of the meeting and proved sufficiently broad to cover all practical aspects of the industry which took place in London last week,

from prospecting to refinery techniques and from hydrocarbon chemistry to rig safety. Although no definitive answer emerged to the vital question of just how large are the world's remaining petroleum reserves, a general consensus emerged that, as far as oil and gas are concerned, the situation is "more optimistic than pessimistic". Since, however, new oilfields can be expected in more and more remote and difficult areas, there will be increasing scope for international cooperation and the pooling of expertise. In some cases, such as the recent proposals for joint Norwegian-Soviet exploration of the Barents Sea, there could be difficulties over lines of demarcation, but so far the atmosphere remains amicable, and the congress heard many accounts of effective and mutually beneficial joint training schemes and transfers of know-how, such as the joint British-Chinese project, which involved on the one hand the training of Chinese technicians aboard North Sea rigs, and on the other a considerable British involvement in the exploration of the South

\section{UK postgraduates}

\section{SERC cracks the whip}

PostgRAduATE students in British universities are taking too long to complete their $\mathrm{PhD}$ theses, according to a survey by the Science and Engineering Research Council (SERC). The survey asked the 59 universities and colleges in Britain how many of the students who began their PhD courses in 1978 had finished them within 4 years by October last year. The table shows the results. Some students who are not still registered after 4 years had left without presenting a thesis, hence the "missing" students in the table. SERC maintains that "writing up results within a reasonable timescale is an integral and important part of research training", and the council has circulated a booklet entitled Research Student and Supervisor: a discussion document on good supervisory practice in an attempt to improve matters.
China Sea

Cautious optimism about world petroleum reserves does not, however, lessen the importance of energy conservation and more efficient recovery and processing methods. Topics discussed at the congress included new methods of obtaining hydrogen from residues, in situ combustion, the recovery of hydrocarbons from oil shales and the liquefaction and gasification of coal.

The formal programme had, however, little to offer in answer to the Prince of Wales, who, in opening the congress suggested that oil entrepreneurs with "imagination and far-sightedness" would doubtless set aside funds to develop new forms of energy to replace oil in the next century. Nevertheless, at least one oil producer is about to diversify - a special number of the Yugoslav petroleum journal Nafta published for the conference reported that the Croatian petroleum production association INA is about to start pilot-plant production of uranim yellow cake from phosphoric acid.

Vera Rich

\section{Cleaner Thames}

THE Thames Water Authority last week jubilantly announced that for the first time in 150 years a salmon had been caught in London's river. The authority began restocking the Thames with salmon in 1979 with the aim of seeing whether the river had been sufficiently freed of pollution to satisfy even the fastidious salmon. For catching the fish, Mr Russell Doig was rewarded with a prize of $£ 250$. What the salmon thought of today's River Thames is open to speculation, but the fish may not have been that impressed, as in Mr Doig's words "For a salmon it didn't put up much of a fight"'.

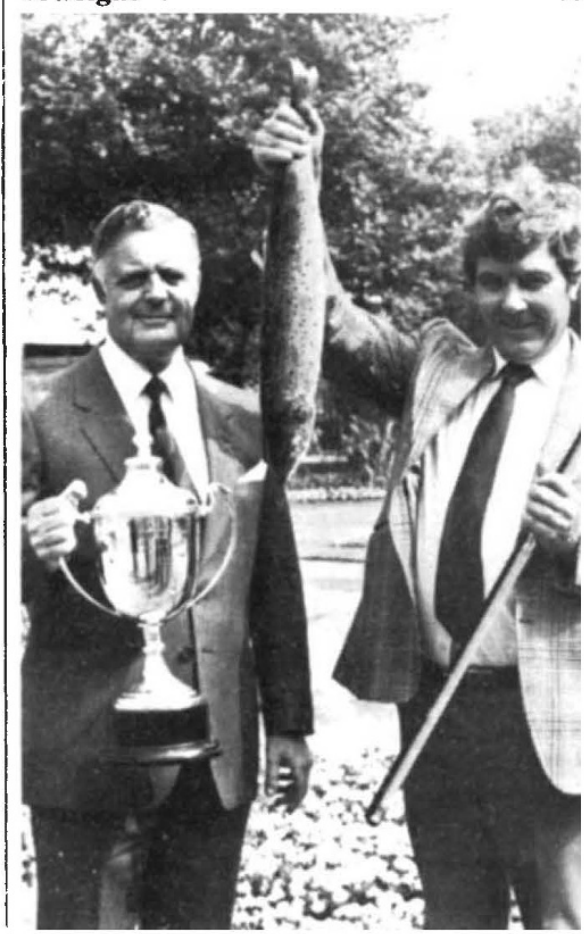

PhD submission by institution

\begin{tabular}{|c|c|c|c|c|c|c|c|}
\hline Universitics & $\begin{array}{l}\text { No. of } \\
\text { students } \\
\text { registered }\end{array}$ & $\begin{array}{c}\text { No, sub- } \\
\text { mitting } \\
\text { by } \\
1.10 .82\end{array}$ & $\begin{array}{c}\text { No. still } \\
\text { registered } \\
\text { at } \\
1.10 .82(\%)\end{array}$ & Universities & $\begin{array}{l}\text { No. of } \\
\text { students } \\
\text { registered }\end{array}$ & $\begin{array}{c}\text { No. sub- } \\
\text { mitting } \\
\text { by } \\
1.10 .82\end{array}$ & $\begin{array}{c}\text { No. still } \\
\text { registered } \\
\text { at } \\
1.10,82(\%)\end{array}$ \\
\hline Aston & 62 & 26 & $21(34)$ & Manchester & 94 & 59 & $29(31)$ \\
\hline Bath & 40 & 19 & 9 (23) & UMIST & 55 & 20 & 9 (16) \\
\hline Birmingham & 67 & 42 & $18(27)$ & Newcastle & 56 & 24 & 30 (54) \\
\hline Bradford & 65 & 36 & $27(42)$ & Nottingham & 72 & 46 & $22(31)$ \\
\hline Bristol & 65 & 36 & $27(42)$ & Open & 8 & 0 & $5(63)$ \\
\hline Brunel & 15 & 7 & 7 (47) & Gxford & 132 & 89 & $30(23)$ \\
\hline Cambridge & 140 & 98 & $32(23)$ & Keading & 33 & 11 & $16(48)$ \\
\hline City & 14 & 5 & 2 (14) & Salford & 41 & 19 & 17 (42) \\
\hline Cranficld Inst. & & & & Shefficld & 69 & 32 & $31(45)$ \\
\hline of Tech. & 10 & 3 & $4(40)$ & Southampton & 62 & 23 & $30(48)$ \\
\hline Durham & 20 & 10 & 9 (45) & Surrey & 32 & 19 & 11 (34) \\
\hline East Anglia & 29 & il & $16(55)$ & Sussex & 46 & 21 & $20(43)$ \\
\hline Essex & 18 & 4 & 9 (50) & Warwick & 36 & 16 & $13(36)$ \\
\hline Excter & 22 & 10 & $12(55)$ & York & 28 & 13 & $14(50)$ \\
\hline Hull & 19 & 10 & $8(42)$ & University of $\mathrm{W}$ ales: & & & \\
\hline Keele & 8 & 6 & $0-$ & Aberystwyth & 18 & 12 & $5(28)$ \\
\hline Kent & 25 & 5 & $14(56)$ & Bangor & 24 & 8 & 8 (33) \\
\hline l.ancaster & 23 & 12 & $5(22)$ & Cardiff & 37 & 15 & $15(41)$ \\
\hline leeds & 95 & 40 & $44(46)$ & Swansea & 28 & 6 & $22(79)$ \\
\hline I. cicester & 38 & 19 & $12(32)$ & UWIST & 10 & 4 & $4(40)$ \\
\hline l.iverpool & 68 & 35 & 29 (43) & Aberdeen & 21 & 11 & 7 (33) \\
\hline I ondon: & & & & Dundee & 13 & 9 & $3(23)$ \\
\hline Bedford & 9 & 3 & $4(44)$ & Edinburgh & 44 & 20 & $21(48)$ \\
\hline Birkbech & 12 & 4 & $8(67)$ & Glasgow & 45 & 22 & $12(27)$ \\
\hline Chelsea & 16 & 7 & $8(50)$ & Heriot-Watt & 24 & 10 & II (46) \\
\hline Imperial & 137 & 67 & $48(35)$ & St Andrews & $2 i$ & 16 & 4 (19) \\
\hline Kings & 24 & 14 & $6(25)$ & Stirling & 7 & 4 & 1 (14) \\
\hline Queen Elizabeth & 21 & 3 & $16(76)$ & Strathclyde & 40 & 22 & 14 (35) \\
\hline Queen Mary & 37 & 11 & $25(68)$ & Queens Belfas! & 1 & 1 & $01-1$ \\
\hline Royal Holloway & 13 & 2 & $8(62)$ & & & & \\
\hline University & 52 & 23 & $23(50)$ & Total universities & 2.297 & 1,124 & $868(38)$ \\
\hline Uestficld & 9 & 4 & $5(56)$ & Total polytechnics & 100 & 35 & 51 (51) \\
\hline Gther institutions & 33 & 14 & 13 (39) & Other institutions & 8 & 1 & $4(50)$ \\
\hline loughborough & 25 & 8 & 14 (56) & Total & 2,405 & 1,160 & 923 (38) \\
\hline
\end{tabular}

